\title{
Analisis Rasio Keuangan Dalam Mengukur Kinerja PT. Adira Dinamika Multi Finance tbk
}

\author{
Asnahwati \\ Sekolah Tinggi Ilmu Ekonomi Riau (STIER) \\ Jln. HR. Subrantas 57 Panam Pekanbaru 28293 Telp. (0761) 63237 \\ E-mail : Asnahwati357@yahoo.com
}

\begin{abstract}
Financial condition will reflect how the performance of the company . Assess the financial performance of the company's goal is to evaluate and improve the state perusahaannya.Untuk measure the financial performance of the company can use financial ratios such as liquidity, solvency, activity and profitability .The purpose of this study is : 1 ) To determine the performance of PT . Adira Multi Finance Tbk terms of liquidity ratios , 2 ) To determine the performance of PT . Adira Multi Finance Tbk terms of solvency ratios , 3 ) To determine the performance of PT . Adira Multi Finance Tbk in terms of the activity ratios and 4 ) To determine the performance of PT. Adira Multi Finance Tbk in terms of the profitability ratio.The analytical method used is the method of comparison is to compare the company's financial ratios with industry standard ratio norm. Based on the analysis of the data obtained it was concluded that : 1 ) The company's performance in terms of the last two year Quick Ratios, has decreased but is generally still above standard industry norms. Means the company still Ilikuit. 2 ) corporate performance in terms of the solvency ratio Debt to Equity Ratio in a state insolvabel, and in terms of Debt to Total Assets Ratio also insolvabel. 3 ) company performance in terms of the ratio of the activity under standard industry norm, so it is said company 's effective yet efficient in utilizing all its assets to finance consumer and 4 ) corporate performance in terms of profitability Economical ( ROA ) in the last two years decreased, although the first 2 years is still above the industry standard norm, while in terms of their own capital profitability ( $\mathrm{ROE}$ ) at 2 years terakir sharp decline and fall below the standard norm industi. Means the company has not been efficient and effective in generating income through all sources of funding available.
\end{abstract}

Keywords: performance, liquidity, solvency, activity and profitability.

Untuk mengetahui kondisi keuangan atau dengan kata lain untuk mengetahui sehat atau tidak sehatnya sebuah perusahaan, bisa dilihat pada rasio keuangannya. Menurut Subramanyam, Halsey dan Wild $(2005 ; 36)$ analisis rasio (ratio analisys) merupakan salah satu alat analisis keuangan yang paling populer dan banyak digunakan. Dalam perjalanan usahanya suatu perusahaan bertujuan untuk memperoleh keuntungan yang maksimal. Namun yang lebih penting lagi perusahaan harus lebih mengutamakan rentabilitas dibanding pencapaian tingkat laba yang besar, karena rentabilitas yang merupakan kemampuan untuk menghasilkan atau menciptakan laba adalah lebih penting daripada pencapaian laba yang besar. Laba yang besar saja belumlah merupakan ukuran bahwa perusahaan itu telah dapat bekerja dengan efisien. Efisien baru dapat diketahui dengan membandingkan laba yang telah diperoleh dengan kekayaan atau modal yang menghasilkan laba tersebut, dengan kata lain menghitung rentabilitasnya.

PT.Adira Finance Tbk. PT Adira Dinamika Multi Finance Tbk (Adira Finance) yang didirikan sejak tahun 1990, merupakan perusahaan pembiayaan konsumen kendaraan bermotor terkemuka di Indonesia. Tekad yang kuat telah menjadikannya sebagai perusahaan yang terbaik dan terpercaya di sektor pembiayaan konsumen kendaraan bermotor di Indonesia. Dari neraca perusahaan ditemukan bahwa peningkatan utang lancar tidak sebanding dengan peningkatan aktiva lancarnya. Hal ini memperlihatkan gejala tidak bagus bagi likuiditas perusahaan. Kemudian pada laporan Laba/ Rugi juga diketahui bahwa persentase peningkatan 
laba sebelum pajak penghasilan belum sebanding dengan persentase peningkatan total aktiva. Hal ini memperlihatkan gejala tidak bagus bagi profitabilitas perusahaan.

Kinerja perusahaan dalam penelitian ini merupakan suatu gambaran tentang kondisi keuangan suatu perusahaan yang dianalisis dengan alat-alat analisis keuangan, sehingga dapat diketahui mengenai baik buruknya keadaan keuangan suatu perusahaan yang mencerminkan prestasi kerja dalam periode tertentu (Munawir, 2000;31).

Menurut Gill dan Chatton (2002), rasio adalah perbandingan suatu hal dengan hal lainnya sehingga dapat menunjukkan hubungan atau korelasi. Rasio keuangan merupakan suatu cara yang membuat perbandingan data keuangan perusahaan menjadi lebih berarti. Menurut Sartono (2008:114) jenis rasio keuangan biasanya dikelompokkan ke dalam empat kelompok rasio yaitu :

a. Rasio Likuiditas, yaitu rasio untuk mengukur kemampuan perusahaan untuk memenuhi kewajiban keuangan jangka pendek tepat pada waktunya.

b. Rasio Aktivitas, yaitu rasio yang menunjukkan sejauh mana efisiensi perusahaan dalam menggunakan asset untuk memperoleh penjualan.

c. Financial Leverage Ratio, yaitu rasio yang menunjukkan kapasitas perusahaan untuk memenuhi kewajiban baik itu jangka pendek maupun jangka panjang.

d. Rasio Profitabilitas, yaitu rasio yang dapat mengukur seberapa besar kemampuan perusahaan dalam memperoleh laba dalam hubungannya dengan penjualan, asset maupun laba bagi modal sendiri.

Penelitian ini memakai angka pembanding standard ratio menurut standart industry yang hanya merupakan kebiasaan dalam menilai hasil analisis rasio keuangan suatu perusahaan (Herispon, 2005:59).

Menurut Munawir $\quad(2009 ; 110)$ Likuiditas adalah kemampuan perusahaan dalam memenuhi kewajiban jangka pendeknya yang telah jatuh tempo, baik kewajiban terhadap pihak luar perusahaan (likuiditas badan usaha) maupun di dalam perusahaan (likuiditas perusahaan).

Solvabilitas adalah kemampuan suatu perusahaan untuk memenuhi segala kewajiban finansialnya apabila sekiranya perusahaan dilikuidasikan (Riyanto, 2008:32-33). Sedangkan Kasmir (2008:151) mengemukakan bahwa rasio solvabilitas atau leverage ratio merupakan rasio yang digunakan untuk mengukur sejauh mana aktiva perusahaan dibiayai dengan utang.

Rasio aktivitas adalah rasio untuk mengukur seberapa efektif perusahaan memanfaatkan semua sumber daya yang ada pada pengendaliannya (Sawir, 2001:14). Sedangkan menurut Masngudi (2006:10) rasio aktivitas adalah rasio untuk mengukur sejauh mana kemampuan perusahaan dalam menggunakan sumber dana yang dimilikinya. Selanjutnya menurut Margaretha (2011:25-26) Asset Manajement Ratio adalah rasio yang mengukur seberapa efektif perusahaan mengelola aktivanya.

Rentabilitas atau Profitability adalah rasio yang menunjukkan kemampuan perusahaan untuk menghasilkan laba selama periode tertentu (Munawir, 2004;33). Rentabilitas suatu perusahaan diukur dengan kesuksesan perusahaan dan kemampuan menggunakan aktivanya secara produktif. Menurut Munawir (2004;33), modal perusahaan pada dasarnya dapat berasal dari pemilik perusahaan (modal sendiri) dan dari para kreditur (modal asing), maka dari itu rentabilitas suatu perusahaan dapat dihitung dengan dua cara, yaitu :

a. Rentabilitas ekonomis

b. Rentabilitas modal sendiri

Rentabilitas ekonomis merupakan perbandingan antara laba usaha dengan seluruh modal yang digunakan (modal sendiri dan modal asing), sedangkan Rentabilitas modal sendiri merupakan perbandingan antara laba yang tersedia untuk pemilik perusahaan dengan jumlah modal sendiri yang dimasukkan oleh 
pemilik perusahaan tersebut (Munawir, 2004;33).

Penelitian Indrawati, Susan Mei (2011) dengan judul "Analisis Laporan Keuangan Dengan Menggunakan Rasio Likuiditas, Solvabilitas dan Rentabilitas Pada PT. BFI FINANCE Tbk" menunjukkan bahwa kinerja keuangan perusahaan dilihat dari tingkat likuiditasnya dikatakan likuid dan mengalami peningkatan. Solvabilitas perusahaan ditinjau dari Total Debt to Total Assets Ratio dikatakan insolvabel, sehingga tidak dapat menjamin utang jangka panjangnya. Namun dari hasil Total Debt to Equity Ratio, perusahaan berada dalam keadaan yang solvabel. Sedangkan dari sisi rentabilitas cenderung mengalami kenaikan baik dari Rentabilitas Ekonomis maupun Rentabilitas Modal Sendiri. Selanjutnya penelitian dengan judul " Analisis Tingkat Perputaran Piutang Pada PT. Adira Finance Makassar" (Nurjanah,2012) menunjukkan bahwa berdasarka rasio RTO (Receivable Turn Over) diketahui tingkat perputaran piutang perusahaan dari tahun ke tahun (2008-2011) mengalami ketidak tetapan (naik-turun). Rasio Average Collection Period (ACP) perusahaan setiap tahunnya cukup baik, sedangkan Rasio tunggakan dan rasio penagihan mengalami ketidak stabilan.

\section{METODE}

Jenis data yang digunakan dalam penelitian ini adalah data sekunder yaitu berupa laporan keuangan yang terdiri dari Neraca dan laporan Laba/Rugi (2009-2011) serta dokumen lain yang bersangkutan dengan penelitian ini.

Dalam penelitian ini penulis menganalisa data dengan menggunakan analisis keuangan deskriptif dengan metode analisis trend yaitu memperbandingkan rasio keuangan perusahaan dari tahun ke tahun dan analisis perbandingan yaitu memperbandingkan rasio keuangan perusahaan dengan rasio standar norma industri.
HASIL

Berdasarkan perhitungan yang telah dilakukan maka hasilnya dapat disajikan pada tabel di berikut ini.

Tabel.1 Rasio Likuiditas berdasarkan Quick Ratio (Dalam Jutaan Rupiah)

\begin{tabular}{|c|r|c|c|}
\hline Tahun & $\begin{array}{c}\text { Aktiva Lancar } \\
\text { (tanpa } \\
\text { persediaan) }\end{array}$ & Utang & Quick \\
\hline 2009 & 4.127 .732 & 1.677 .146 & $246,12 \%$ \\
\hline 2010 & 7.330 .149 & 3.804 .856 & $192,65 \%$ \\
\hline 2011 & 16.402 .215 & 12.468 .083 & $131,55 \%$ \\
\hline
\end{tabular}

Sumber: Data Olahan (2013)

Dari tabel.1 di atas dapat dilihat perkembangan likuiditas perusahaan berdasarkan quick ratio telah mengalami fluktuasi setiap tahunnya. Quick ratio pada dua tahun pertama masih berada di atas standar norma industri yang biasa digunakan oleh banyak perusahaan yaitu sebesar $150 \%$, tetapi pada tahun ketiga terjadi penurunan likuiditas. Penurunan likuiditas ini menunjukkan penurunan kinerja perusahaan.

\section{Mengukur Debt to Equity Ratio}

Berdasarkan perhitungan yang telah dilakukan maka hasilnya dapat disajikan pada tabel berikut ini :

Tabel 2. Debt to EquityRatio (Dalam Jutaan Rupiah)

\begin{tabular}{|l|c|c|c|}
\hline Tahun & $\begin{array}{c}\text { Jumlah } \\
\text { Ekuitas }\end{array}$ & $\begin{array}{c}\text { Total } \\
\text { utang }\end{array}$ & $\begin{array}{c}\text { Debt to } \\
\text { Equity } \\
\text { Ratio }\end{array}$ \\
\hline 2009 & 2.652 .403 & 1.677 .146 & 1,58 \\
\hline 2010 & 3.794 .759 & 3.804 .856 & 1,00 \\
\hline 2011 & 4.421 .369 & 12.468 .083 & 0,35 \\
\hline
\end{tabular}

Sumber : Data Olahan (2013)

Dari tabel 2. di atas dapat dilihat perkembangan solvabilits perusahaan berdasarkan Debt to Equity Ratio telah mengalami penurunan yang tajam setiap tahunnya dan berada di bawah standar norma industri yaitu sebesar 2,0. Itu artinya 
belum terjaminnya seluruh utang perusahaan kepada kreditur.

\section{Mengukur Debt to Total Asset Ratio}

Berdasarkan perhitungan yang telah dilakukan maka hasil dari penelitian ini disajikan pada tabel berikut ini :

Tabel 3. Debt to Total Asset Ratio (Dalam Jutaan Rupiah)

\begin{tabular}{|c|r|r|c|}
\hline Tahun & Total Aset & Total utang & $\begin{array}{c}\text { Debt to } \\
\text { Total Asset } \\
\text { Ratio }\end{array}$ \\
\hline 2009 & 4.329 .549 & 1.677 .146 & $258 \%$ \\
\hline 2010 & 7.599 .615 & 3.804 .856 & $200 \%$ \\
\hline 2011 & 16.889 .452 & 12.468 .083 & $136 \%$ \\
\hline
\end{tabular}

Sumber : Data Olahan (2013)

Dari tabel 3. di atas dapat dilihat perkembangan solvabilitas perusahaan berdasarkan Deb to Total Asset Ratio telah mengalami penurunan yang tajam setiap tahunnya dan masih berada di bawah standart norma industri yaitu sebesar 250\%. Itu artinya belum terjaminnya utang (utang jangka pendek dan utang jangka panjang) perusahaan kepada kreditur jika perusahaan dilikuidasi.

\section{Analisis Aktivitas}

Berdasarkan perhitungan yang telah dilakukan maka hasilnya dapat disajikan pada tabel berikut ini :

Tabel 4.Total Asset Turn Over Ratio (Dalam Jutaan Rupiah)

\begin{tabular}{|l|l|l|l|}
\hline Tahun & Total asset & $\begin{array}{l}\text { Pembiayaan } \\
\text { Konsumen }\end{array}$ & $\begin{array}{l}\text { Total Asset } \\
\text { Turn Over }\end{array}$ \\
\hline 2009 & 4.329 .549 & 2.777 .866 & 0,64 \\
\hline 2010 & 7.599 .615 & 2.118 .888 & 0,28 \\
\hline 2011 & 16.889 .452 & 3.008 .350 & 0,18 \\
\hline
\end{tabular}

Sumber : Data Olahan (2013)

Dari tabel 4. di atas dapat dilihat perkembangan aktivitas perusahaan berdasarkan total asset turn over telah mengalami penurunan yang tajam setiap tahunnya.

\section{Analisis Profitabilitas / Rentabilitas}

Dari perhitungan yang telah dilakukan maka hasilnya dapat disajikan pada tabel berikut ini :
Tabel 5. Rentabilitas Ekonomis (Dalam Jutaan Rupiah)

\begin{tabular}{|c|c|c|c|}
\hline Tahun & $\begin{array}{c}\text { Laba } \\
\text { Sebelum } \\
\text { Bunga dan } \\
\text { pajak }\end{array}$ & $\begin{array}{c}\text { Total } \\
\text { Aktiva }\end{array}$ & $\begin{array}{c}\text { Rasio } \\
\text { Rentabilitas } \\
\text { Ekonomis }\end{array}$ \\
\hline 2009 & 1.658 .347 & 4.329 .549 & $38,3 \%$ \\
\hline 2010 & 1.931 .723 & 7.599 .615 & $25,42 \%$ \\
\hline 2011 & 2.111 .539 & 16.889 .452 & $12,50 \%$ \\
\hline
\end{tabular}

Sumber : Data Olahan (2013)

Dari tabel 5. di atas dapat dilihat perkembangan rentabilitas perusahaan berdasarkan Rentabilitas Ekonomis mengalami penurunan yang tajam. Ini memperlihatkan kinerja perusahaan yang juga semakin menurun dan kurang baik.

\section{Rentabilitas Modal Sendiri (ROE)}

Setelah dilakukan perhitungan, maka hasilnya dapat disajikan dalam tabel berikut ini

\section{Tabel 6 Rentabilitas Modal Sendiri} (Dalam Jutaan Rupiah)

\begin{tabular}{|c|c|c|c|}
\hline Tahun & $\begin{array}{c}\text { Laba } \\
\text { Setelah } \\
\text { Pajak }\end{array}$ & $\begin{array}{c}\text { Total } \\
\text { Ekuitas }\end{array}$ & $\begin{array}{l}\text { Rasio } \\
\text { Rentabilitas } \\
\text { Modal } \\
\text { Sendiri }\end{array}$ \\
\hline 2009 & 1.212 .400 & 2.652 .403 & $45.71 \%$ \\
\hline 2010 & 1.467 .906 & 3.794 .759 & $38,68 \%$ \\
\hline 2011 & 1.583 .321 & 4.421 .369 & $35.81 \%$ \\
\hline
\end{tabular}

Sumber : Data Olahan (2013)

Dari tabel 6. terlihat juga bahwa rentabilitas perusahaan terus mengalami penurunan pada dua tahun terakhir. Ini memperlihatkan kinerja perusahaan yang juga semakin menurun. Berikut ini rekapitulasi data penelitian: 
Tabel 7. Rekapitulasi Data Penelitian

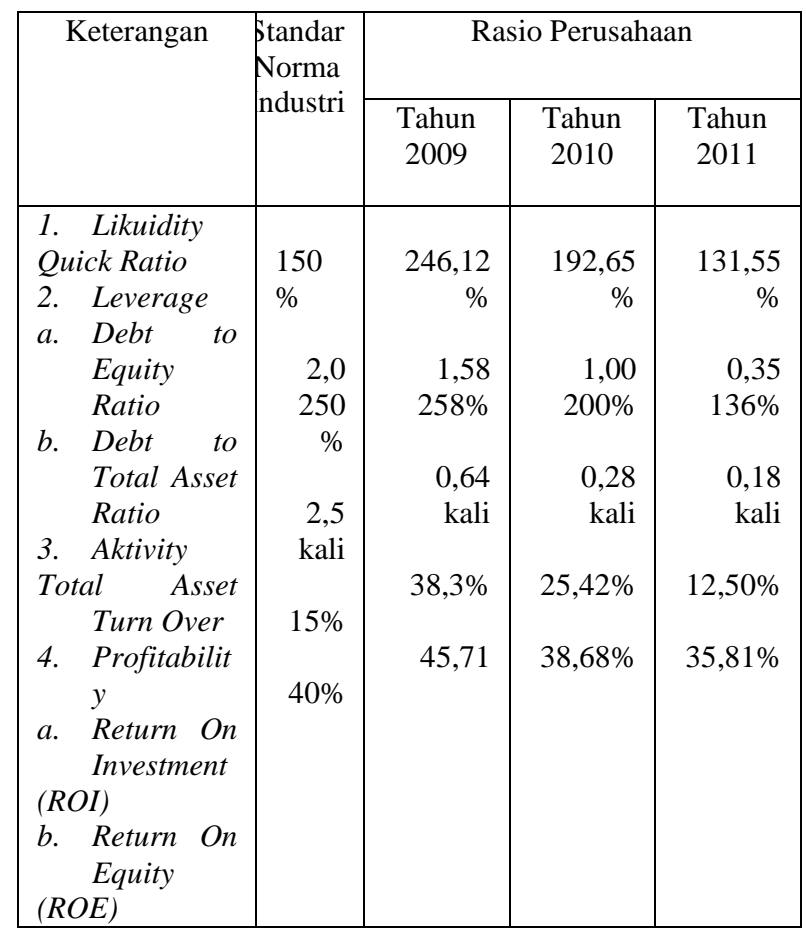

\section{PEMBAHASAN}

Berdasarkan dari hasil penelitian yang diperoleh dapat diketahui bahwa quick ratio perusahaan selalu menurun. Dua tahun pertama berada di atas standar norma industri yaitu $150 \%$ dan tahun ketiga berada di bawah standar norma industri. Ini artinya selama dua tahun pertama masih terjaminnya utang-utang jangka pendek perusahaan kepada kreditur tetapi pada tahun ketiga sudah tidak terjamin lagi. Ini menunjukkan penurunan pada kinerja keuangan perusahaan. Hal ini disebabkan oleh pertumbuhan aktiva lancar yang lebih kecil bila dibandingkan dengan pertumbuhan pasiva lancar.

Rasio solvabilitas Adira Finance ditinjau dari debt to equity ratio selalu mengalami penurunan setiap tahunnya dan selalu berada di bawah standar norma industri yaitu 2,0. Ini menunjukkan belum terjaminnya seluruh utang baik utang jangka panjang maupun utang jangka pendek kepada kreditur jika saat itu perusahaan dilikuidasikan atau ditutup. Sedangkan solvabilitas ditinjau dari debt to total asset ratio juga selalu menurun setiap tahunnya.
Tahun pertama penelitian masih berada di atas standar norma industri dan dua tahun berikutnya berada di bawah standar norma industri. Ini menunjukkan kemampuan perusahaan yang kurang baik untuk memenuhi semua kewajibannya saat dilikuidasikan dan ini juga menunjukkan kinerja perusahaan yang kurang baik.

Dari hasil penelitian juga diketahui bahwa rasio aktivitas berdasarkan Total Asset Turn Over Ratio, juga selalu mengalami penurunan yang tajam dan selalu berada di bawah standar norma industri. Berarti perusahaan belum efisien dan efektif dalam mendayagunakan semua sumber aset yang dimiliki perusahaan untuk membiayai konsumen. Hal ini menunjukkan kinerja perusahaan yang kurang baik.

Rentabilitas perusahaan ditinjau dari rentabilitas ekonomis (ROI) juga selalu mengalami penurunan tetapi masih berada di atas standar norma indusri $15 \%$. Ini artinya perusahaan masih produktif dan efisien dalam menghasilkan laba usahanya. Menurunnya rentabilitas ekonomis pada tahun 2010 disebabkan oleh meningkatnya total aktiva yang digunakan dengan tajam dibandingkan peningkatan jumlah laba usaha yang dihasilkan. Ini berarti perusahaan dalam keadaan kurang produktif dan kurang efisien dalam menghasilkan laba usaha. Ini memperlihatkan penurunan kinerja perusahaan karena semakin menurunnya kemampuan perusahaan dalam menggunakan seluruh aktivanya dalam menghasilkan laba. Kemudian pada tahun ketiga penelitian ROE berada di bawah standar industri. Ini artinya perusahaan sudah tidak efisien dan efektif dalam menggunakan modal sendiri untuk menghasilkan laba bersih.

\section{SIMPULAN}

Rasio likuiditas PT. Adira Dinamika Multi Finance Tbk ditinjau dari quick ratio mengalami penurunan setiap tahunnya. Dua tahun pertama masih berada di atas standart norma industri yaitu $150 \%$ tetapi pada tahun ketiga berada di bawah standar 
industri. Artinya perusahaan telah Illikuid atau dikatakan juga kinerja perusahaan dari segi likuiditas adalah kurang baik.

Solvabilitas perusahaan ditinjau dari debt to equity ratio selalu menurun dengan tajam dan selalu berada di bawah standar norma industri. Demikian juga ditinjau dari debt to total asset ratio juga selalu menurun dengan tajam. Tahun pertama masih berada di atas standar norma industri kemudian dua tahun berikutnya berada di bawah standar industri. Artinya perusahaan dalam keadaan insolvabel dan menunjukkan kinerja perusahaan ditinjau dari rasio solvabilitas dikatakan kurang baik.

Aktivitas perusahaan ditinjau dari Total Asset Turn Over (TATO) selalu menurun dan selalu berada di bawah standar industri. Ini menunjukkan kinerja perusahaan ditinjau dari rasio aktivitas adalah kurang baik.

Rentabilitas perusahaan ditinjau dari rentabilitas ekonomis juga mengalami penurunan setiap tahunnya. Tahun pertama masih berada di atas standar industri tapi pada dua tahun berikutnya berada di bawah standar norma industri. Ini menunjukkan kinerja perusahaan ditinjau dari rentabilitas ekonomis adalah kurang baik. Demikian juga ditinjau dari rentabilitas modal sendiri juga selalu mengalami penurunan yang tajam setiap tahunnya. Berarti kinerja perusahaan ditinjau dari ROE adalah kurang baik.

\section{DAFTAR RUJUKAN}

Alwi, S, Alat-alat Analisa Dalam Pembelanjaan, Edisi Ketiga, Cetakan Pertama, Andi Offset, Yogyakarta, 2002.

Gill, James O, Moira Chatton, Memahami Laporan Keuangan, PPM, Jakarta, 2008.

Husnan, S, Manajemen Keuangan II, Edisi Ketiga, AMP, YPKN, Yogyakarta, 2002.
Herispon, Manajemen keuangan I, UIR PRESS, Pekanbaru, 2004.

Herispon, Analisis Laporan Keuangan (Financial Statement Analisys).UIR PRESS

Pekanbaru, 2005.

Ikatan Akuntansi Indonesia, Standar Akuntansi Keuangan, Jakarta, Salemba Empat, 2010.

Indarwati, Susan Mei, Analisis Laporan Keuangan Dengan Menggunakan Rasio Likuiditas, Solvabilitas dan Rentabilitas Pada PT. BFI FINANCE Tbk. Jurusan Manajemen, Fakultas Ekonomi, Universitas Gunadarma, 2011.

Kasmir, Analisis Laporan Keuangan, Rajawali Pers (Divisi Buku Perguruan Tinggi

PT. Raja Grafindo Persada), Jakarta, 2008.

K. R. Subramanyam, Robert F. Halsey, John J. Wild, Financial Statement Analist (Analisis Laporan Keuangan), Edisi 8, Buku satu, TerjemahanYanivi S, Bachtiar, S.Nurwahyu Harahap, Penerbit Salemba Empat, Jakarta, 2005.

Masngudi, Manajemen Keuangan, Diklat Materi Kuliah, Padang, 2006.

Munawir, S, Analisis Laporan Keuangan, Liberty Yogyakarta, Yogyakarta, 2004.

Mariani, Analisis Rasio Keuangan Pada PT. Tri Bakti Sarimas Bukit Payung, Unpublished Skripsi, Sekolah Tinggi Ilmu Ekonomi - Riau (STIER), Pekanbaru, 2010.

Mahmud, M.Hanafi dan Hakim, Abdul, Analisis Laporan Keuangan, Edisi Revisi, UPP Amp YKPN, 2003. 
Margaretha, Farah, Manajemen Keuangan, Untuk Manajer Non Keuangan, Erlangga, Jakarta,2011.

Riyanto, B, Dasar-Dasar Pembelanjaan Perusahaan, EdisiKeempat, FE Universi-

Tas Gajah Mada, Yogyakarta, 2001.

Riyanto, Bambang, DasardasarPembelajaran Perusahaan, BPFE, Yogyakarta, 2008.

Supriyono, Nanang, Analisis Rasio Keuangan Padan Koperasi Unit Desa Makmur Sungai Sirih Singingi, Unpublikashed Skripsi, Sekolah Tinggi Ilmu Ekonomi- Riau (STIE-R), 2007.

Sudana, I Made, Manajemen Keuangan Perusahaan, Erlangga, Jakarta, 2011.
Sawir, Agnes, Analisis Kinerja Keuangan dan Perencanaan Keuangan Perusahaan, Pt.GramediaPustakaUtama, Jakarta, 2005.

Sawir, Agnes, Analisa Kinerja Keuangan dan Perencanaan keuangan Perusahaan, PT. Gramedia Pustaka Utama, Jakarta, 2001.

Syamsuddin, Lukman, Manajemen Keuangan Perusahaan, PT. Raja Grafindo Persada, Jakarta, 2001.

Sartono, Agus, Manajemen Keuangan, Edisi Keempat, BPFE, Universitas Gadjah Mada, Yogyakarta, 2004. 